\title{
Effect of dietary molasses on the site and extent of digestion of nutrients in sheep fed broiler litter
}

\author{
D.T. Mavimbela and J.B.J. van Ryssen ${ }^{\#}$ \\ Department of Animal and Wildlife Sciences, University of Pretoria, Pretoria 0002, South Africa
}

\begin{abstract}
The aim of this experiment was to determine the site and extent of digestion of nutrients in sheep fed broiler litter alone (100\% litter treatment), broiler litter plus $7.5 \%$ sugarcane molasses $(92.5 \%$ litter treatment) and broiler litter plus $15 \%$ molasses ( $85 \%$ litter treatment). Voluntary intake was increased by molasses, apparently due to an increased rate of passage of digesta through the digestive tract. This resulted in a shift in the site of disappearance of organic matter (OM) from the rumen towards the lower digestive tract. For the 100 and $92.5 \%$ litter treatments, 0.37 and 0.46 of dietary OM disappeared in the rumen respectively, compared to 0.21 for the $85 \%$ litter treatment, while $0.16,0.08$ and 0.35 of dietary OM disappeared in the small intestine for the 100, 92.5 and 85\% litter diets respectively. In the case of the $85 \%$ litter treatment, 0.26 of dietary nitrogen $(\mathrm{N})$ disappeared in the rumen and 0.45 in the small intestine, compared to 0.55 and 0.62 in the rumen and 0.18 and 0.11 in the small intestine for the 100 and $92.5 \%$ litter diets respectively. There were no differences between treatments for total tract apparent digestibility of $\mathrm{N}$ (0.73) and OM (0.65-0.73), rumen degradability of $\mathrm{N}(71-87 \%)$ or concentration of ammonia- $\mathrm{N}$ in rumen fluid $(53 \mathrm{mg} / 100 \mathrm{ml})$. It was concluded that the addition of molasses might be advantageous when the intake of litter is restricted or when voluntary intake of litter is unacceptably low.
\end{abstract}

Keywords: broiler litter, sheep, nutrition, molasses, digestion

\#Author to whom correspondence should be addressed. E-mail: jvryssen@postino.up.ac.za

\section{Introduction}

Many farmers in southern Africa use poultry manure as a livestock feed during protracted droughts or after the destruction of forage resources by fire (Mavimbela et al., 1997). The potential problems associated with the use of poultry manure or litter as a feedstuff have been investigated extensively. Many studies have emphasised that precautionary measures should be employed when feeding this product, which may be nutritionally unbalanced or pose a health-risk to the animal (Fontenot \& Jurubescu, 1980; Fontenot, 1991; Rankins et al., 1993; Mavimbela et al., 1997; Ruffin \& McCaskey, 1998).

According to Fontenot (1991), broiler litter has a high crude protein concentration, consisting mainly of non-protein nitrogen (NPN), and is deficient in available energy. When high levels of litter are fed, molasses is often added as a source of energy that is readily available to the rumen microbes to complement the high nitrogen $(\mathrm{N})$ concentration of litter (Mavimbela et al., 1997). Little information has been published on the digestion of nutrients when litter constitutes all or most of the diet. The aim of this experiment was to determine the site and extent of digestion of nutrients in sheep fed broiler litter alone, broiler litter plus $7.5 \%$ sugarcane molasses and broiler litter plus $15 \%$ molasses.

\section{Materials and Methods}

Six mature South African Mutton Merino wethers (54 kg mean body weight) were used. The sheep were equipped with rumen, abomasal and terminal ileal cannulae. The wethers were randomly allocated to treatments consisting of pure broiler litter or litter mixed with $7.5 \%$ sugarcane molasses or $15 \%$ molasses in a 3 x 3 Latin square design, i.e. two wethers per treatment per period; six animals per treatment. The broiler litter that was used had been sun-dried and contained wood shavings that had been included as bedding material. The litter was passed through a $2.5 \mathrm{~cm}$ sieve to remove lumps and foreign material. The sheep were vaccinated against botulism and treated with a broad-spectrum anthelmintic three weeks prior to the trial. Sheep were allowed to adapt to the diets for 14 days between dietary treatments. Diets were offered $a d$ libitum, and animals had free access to water. Feed intake was recorded and representative feed samples were taken. The experiment was conducted with the approval of the Ethics Committee for Animal Experimentation of the University of Pretoria.

The double marker technique (Faichney, 1975) was used for estimation of partial digestibility, with 
chromium (Cr-EDTA; Downes \& McDonald, 1964) and ytterbium (Yb-acetate; Siddons et al., 1985) as liquid and particulate phase markers respectively. The Cr-EDTA and $\mathrm{Yb}$-acetate were prepared according to the methods described by Morgan et al. (1976), and predetermined daily doses were infused continuously into the rumen using a peristaltic pump. From day five of infusion, ruminal, abomasal and ileal contents were collected over a period of four days. A discontinuous sampling schedule was followed to minimise disturbance of the normal flow of digesta. Samples of rumen, abomasal and ileal digesta were collected as follows: at 9:00 and 21:00 on day 5; at 12:00 and 24:00 on day 6; at 15:00 and 03:00 on day 7; at 18:00 and 06:00 hours on day 8.

Rumen samples were strained through six layers of cheesecloth, and the fluid fractions were preserved with $50 \%(\mathrm{v} / \mathrm{v})$ sulphuric acid for ammonia nitrogen $\left(\mathrm{NH}_{3}-\mathrm{N}\right)$ assay. Abomasal and ileal digesta samples were frozen at $-20^{\circ} \mathrm{C}$. Faeces were collected twice daily and aliquots were stored at $-20^{\circ} \mathrm{C}$. After thawing, composite samples of abomasal and ileal digesta were centrifuged and the supernatant stored at $20^{\circ} \mathrm{C}$ pending $\mathrm{Cr}, \mathrm{Yb}$ and $\mathrm{NH}_{3}-\mathrm{N}$ analyses. Digesta and faecal samples were dried at $60^{\circ} \mathrm{C}$ and ground. $\mathrm{Cr}$ and $\mathrm{Yb}$ concentrations in abomasal and ileal samples (total and supernatant) were determined by atomic absorption spectrophotometry. The $\mathrm{NH}_{3}-\mathrm{N}$ concentrations in ruminal and composite abomasal and ileal samples were determined with an auto analyzer (Technicon Auto-Analyzer II; Industrial method No. 33474A). The ash and $\mathrm{N}$ concentrations of feed, faeces and composite abomasal and ileal samples, and dietary phosphorus content were determined using standard AOAC (1990) procedures. Neutral detergent fibre and acid detergent fibre concentrations in the diets were determined according to the procedure of Robertson \& Van Soest (1981). The purine method (Zin \& Owens, 1986) was used to determine the microbial N concentration of abomasal contents. The ratio of purine- $\mathrm{N}$ to total $\mathrm{N}$ in microbes was estimated from analysis of rumen bacteria collected from sheep consuming only broiler litter. Atomic absorption spectrophotometry was used to determine the calcium, magnesium, sodium, potassium, copper, manganese and zinc concentrations of the diets. A hydride generator was attached to the atomic absorption spectrophotometer for assay of selenium concentrations in the diets. The dry sieve technique with a maximum sieve diameter of $2 \mathrm{~mm}$ was used to measure the distribution of particle sizes of the litter.

Abomasal and ileal digesta flows were calculated using $\mathrm{Cr}$ as liquid phase marker and $\mathrm{Yb}$ as particulate marker (Faichney, 1975). Total digesta flows were reconstituted according to marker concentrations in fractionated and unfractionated digesta. Organic matter (OM) and $\mathrm{N}$ disappearance in the various regions of the digestive tract was calculated as the difference in digesta flow (or intake/excreted) before and after the specific section. Non-ammonia nitrogen (NAN) was assumed to represent the $\mathrm{N}$ in true protein and was calculated as the difference between total $\mathrm{N}$ and $\mathrm{NH}_{3}-\mathrm{N}$ flows at a specific site.

Statistical analyses appropriate for a latin square design were conducted using SAS (1994), and a Tukey test was used to determine the significance of differences. Treatment, animal and period effects were included in the analysis.

\section{Results}

The chemical composition of the broiler litter is presented in Table 1. The addition of molasses did not change the composition substantially except for slight increases in the concentration of potassium. Particles greater than $2 \mathrm{~mm}$ in diameter constituted $41 \%$ of the litter, and particles less than $1 \mathrm{~mm}$ in diameter constituted $52 \%$.

Dry matter intake increased $(\mathrm{P}<0.05)$ with an increase in molasses inclusion in the diet, viz. (mean \pm s.e.) $858 \pm 251,1123 \pm 342$ and $1366 \pm 413 \mathrm{~g} / \mathrm{d}$, constituting $1.9 \%, 2.4 \%$ and $3.0 \%$ of body weight for the $100 \%, 92.5 \%$ and $85 \%$ litter treatments respectively. This trend was also evident for OM intake, and a higher flow rate of digesta through the abomasum and ileum was observed for the high molasses treatment (Table 2). Apparent OM digestibility was lower $(\mathrm{P}<0.05)$ in the rumen and higher $(\mathrm{P}<0.05)$ in the small intestine for the $85 \%$ litter treatment than for the other treatments. Consequently, a larger proportion of dietary OM disappeared in the small intestine $(0.35)$ than in the rumen $(0.21)$ with the $85 \%$ litter diet - a trend not observed with the other two treatments. However, total apparent OM digestibility did not differ significantly between treatments $(\mathrm{P}>0.05)$. Faecal DM concentration for the $85 \%$ litter treatment (mean \pm s.e.: $40.8 \pm 3.5 \%)$ was lower $(\mathrm{P}<0.05)$ than that for the $100 \%(49.5 \pm 2.7)$ or $92.5 \%(47.3 \pm 4.8 \%)$ litter treatments. 
Table 1 Chemical composition of broiler litter (dry matter basis)

\begin{tabular}{lc}
\hline & $\mathrm{g} / \mathrm{kg}$ \\
\hline & \\
Dry matter & 850 \\
Organic matter & 820 \\
Crude protein & 190 \\
Neutral detergent fibre & 410 \\
Acid detergent fibre & 280 \\
Calcium & 130 \\
Phosphorus & 130 \\
Magnesium & 20 \\
Potassium & 11.2 \\
Sodium & 2.4 \\
& \\
& $\mathrm{mg} / \mathrm{kg}$ \\
Manganese & 290 \\
Copper & 58 \\
Selenium & 0.94 \\
Zinc & 222 \\
\hline
\end{tabular}

Table 2 Means ( \pm s.e.) for intake, flow and apparent digestion of organic matter $(\mathrm{OM})$ in various segments of the digestive tract of sheep fed diets containing $100,92.5$ or $85 \%$ broiler litter

\begin{tabular}{lccc}
\hline Broiler litter (\%) & 100 & 92.5 & 85 \\
Molasses (\%) & 0 & 7.5 & 15 \\
\hline & $732 \pm 241$ & $986 \pm 329$ & $1133 \pm 397$ \\
OM intake (g/d) & & & \\
& & $532 \pm 634$ & $901 \pm 308$ \\
Total OM flow (g/d) & $459 \pm 286$ & $450 \pm 401$ & $509 \pm 171$ \\
At abomasum & $341 \pm 215$ & & \\
At terminal ileum & & & $0.21 \pm 0.109^{\mathrm{b}}$ \\
OM apparently digested (proportion of OM intake) & $0.46 \pm 0.102^{\mathrm{a}}$ & $0.35 \pm 0.152^{\mathrm{b}}$ \\
Rumen & $0.37 \pm 0.187^{\mathrm{a}}$ & $0.082 \pm 0.046^{\mathrm{a}}$ & $0.08 \pm 0.029$ \\
Small intestine & $0.16 \pm 0.067^{\mathrm{a}}$ & $0.073 \pm 0.016$ & $0.64 \pm 0.106$ \\
Large intestine & $0.062 \pm 0.029$ & $0.62 \pm 0.091$ & \\
Total tract & $0.59 \pm 0.145$ & & \\
\hline
\end{tabular}

Means within rows with different superscripts differ significantly $(\mathrm{P}<0.05)$

The inclusion of $15 \%$ molasses in the diet resulted in a higher, though non-significantly different $(\mathrm{P}$ $>0.05) \mathrm{N}$ intake compared to the other two treatments. However, this resulted in significantly higher $(\mathrm{P}<$ 0.05 ) flow rates of total $\mathrm{N}, \mathrm{NAN}$ and microbial $\mathrm{N}$ through the abomasum for the $85 \%$ litter treatment compared to the other treatments (Table 3). The $\mathrm{NH}_{3}-\mathrm{N}$ concentrations in ruminal fluid did not differ between treatments. Microbial N constituted $62-72 \%$ of abomasal NAN. The rumen degradability of $\mathrm{N}$ in broiler litter, as estimated from these results, was between 71 and $86 \%$ (Table 3). Nitrogen disappearance was higher $(\mathrm{P}<0.05)$ in the rumen and lower in the small intestine $(\mathrm{P}<0.05)$ for the $100 \%$ and $92.5 \%$ litter diets than for the $85 \%$ litter treatment, although apparent $\mathrm{N}$ digestibility for the digestive tract as a whole did not differ significantly between treatments (Table 3). Microbial $\mathrm{N}$ apparently synthesized per $\mathrm{kg}$ of $\mathrm{OM}$ digested in the rumen was $27.8,16.1$ and $75.3 \mathrm{~g}$ for the $100,92.5$ and $85 \%$ litter diets respectively. 
Table 3 Mean ( \pm s.e.) nitrogen $(\mathrm{N})$ intake, flow and apparent digestion in various segments of the digestive tract of sheep fed diets containing $100,92.5$ or $85 \%$ broiler litter

\begin{tabular}{|c|c|c|c|}
\hline Broiler litter (\%) & 100 & 92.5 & 85 \\
\hline Molasses (\%) & 0 & 7.5 & 15 \\
\hline $\mathrm{N}$ intake $(\mathrm{g} / \mathrm{d})$ & $31.3 \pm 12.3$ & $43.8 \pm 15.5$ & $52.0 \pm 25.7$ \\
\hline \multicolumn{4}{|l|}{ Total N flow (g/d) } \\
\hline Abomasum: Total N & $14.1 \pm 8.9^{\mathrm{a}}$ & $17.8 \pm 8.8^{\mathrm{a}}$ & $39.3 \pm 20.8^{b}$ \\
\hline Abomasum: NAN & $12.0 \pm 3.1^{\mathrm{a}}$ & $15.1 \pm 3.2^{\mathrm{a}}$ & $34.3 \pm 21.3^{\mathrm{b}}$ \\
\hline Abomasum: Microbial N & $8.6 \pm 2.5^{\mathrm{a}}$ & $10.4 \pm 2.0^{\mathrm{a}}$ & $15.9 \pm 2.2^{\mathrm{b}}$ \\
\hline Terminal ileum: NAN & $5.1 \pm 2.6$ & $6.0 \pm 1.7$ & $6.2 \pm 2.6$ \\
\hline \multicolumn{4}{|c|}{ Indicators of the apparent fate of $\mathrm{N}$ in the rumen } \\
\hline $\mathrm{NH}_{3}-\mathrm{N}(\mathrm{mg} / 100 \mathrm{ml})$ & $51 \pm 11.5$ & $56 \pm 12.1$ & $51 \pm 12.5$ \\
\hline Degradability $(\%)$ & $86.7 \pm 8.71$ & $86.5 \pm 10.65$ & $71.4 \pm 28.17$ \\
\hline \multicolumn{4}{|l|}{ Microbial $\mathrm{N}$ as $\%$ of: } \\
\hline Abomasal NAN* & $72.4 \pm 15.4$ & $70.1 \pm 13.4$ & $62.8 \pm 34.6$ \\
\hline $\mathrm{N}$ intake & $30.8 \pm 12.5$ & $26.1 \pm 8.8$ & $38.6 \pm 21.6$ \\
\hline \multicolumn{4}{|c|}{$\mathrm{N}$ apparently digested (proportion of $\mathrm{N}$ intake) } \\
\hline Rumen $(\mathrm{N})$ & $0.55 \pm 0.19^{\mathrm{a}}$ & $0.62 \pm 0.14^{\mathrm{a}}$ & $0.26 \pm 0.17^{\mathrm{b}}$ \\
\hline Small intestine (NAN) & $0.18 \pm 0.06^{\mathrm{a}}$ & $0.11 \pm 0.02^{\mathrm{a}}$ & $0.45 \pm 0.095^{b}$ \\
\hline Total tract $(\mathrm{N})$ & $0.72 \pm 0.073$ & $0.72 \pm 0.042$ & $0.73 \pm 0.044$ \\
\hline
\end{tabular}

\section{Discussion}

The apparent DM digestibility (total digestive tract) of broiler litter varied between 0.65 and 0.68 . This compares well with published values (calculated by difference) of 0.69-0.74 (Bhattacharya \& Fontenot, 1966), 0.50 (Rankins et al., 1993) and 0.57-0.58 (Rude \& Rankins, 1997). Similarly, the total tract apparent digestibility of OM ranged between 0.54 and 0.64 , and compared well with reported OM digestibilities of 0.64 (Fontenot \& Jurubescu, 1980), 0.44 and 0.47 (Patil et al., 1995), 0.56 and 0.58 (Chaudhry et al., 1996) and 0.42-0.46 (Rossi et al., 1996). The apparent digestibility of $\mathrm{N}$ in litter was 0.72 in the present study. This agrees with estimates of 0.72 and 0.74 (Bhattacharya \& Fontenot, 1966), 0.67-0.73 (Patil et al., 1995), 0.61-0.71 (Chaudhry et al., 1996) and 0.84 (Zinn et al., 1996). Considering the digestibility of OM in litter, the statement that broiler litter is deficient in available energy (Fontenot, 1991) is only correct in the sense that it is low relative to the high crude protein concentration of the product.

The increase in voluntary DM intake observed with increasing additions of molasses to the broiler litter is in agreement with the findings of a previous study (Mavimbela et al., 1997). Silanikove et al. (1987) observed a high intake of litter by beef cows and concluded that the small particle size of broiler litter resulted in fast escape from the rumen and a relatively high intake. However, others are of the contention that the physical and chemical nature of broiler litter is conducive to a lack of rumen stimulation with low saliva flow and voluntary intake (Patil et al., 1995; Rossi et al., 1996), and to bloat in cattle (Ruffin \& McCaskey, 1998). Patil et al. (1995) suggested that the passage rate of ruminal digesta of diets containing high levels of broiler litter (viz. 50\%) is low when dietary roughage levels are low, resulting in low feed intake. No signs of bloat were noticed in our study although DM intake for the $100 \%$ litter treatment was only $1.9 \%$ of body weight, which is low for sheep. A possible explanation for this disparity could be that the average particle size of litter used in the present study was higher $(41 \%$ of particles were greater than $2 \mathrm{~mm}$ in diameter) than that used in the other studies; this would have stimulated rumination more than in the other studies. Rossi et al. (1996) recorded average particle sizes for litter samples collected in the USA of 1.53, $1.05,0.85$ and $0.79 \mathrm{~mm}$. The difference between the particle size of litter used in this study (representative of the South African product) and the USA samples could be the result of different broiler rearing practices. In the USA five to six batches of broilers are commonly reared in a house before the litter is removed (Park et al., 1995; Patil et al., 1995; Rude \& Rankins, 1997), while in South Africa broiler houses are usually cleaned after each batch of birds. 
According to Ruffin \& McCaskey (1998), broiler litter tends to become dusty and unpalatable for cattle when it contains less than $12 \%$ moisture. The addition of molasses in the present study might have decreased the dustiness of the litter, and thus improved intake. To what extent the $15 \%$ molasses had a laxative effect and thus increased the rate of passage of the digesta through the digestive tract, is not clear. Although the DM concentration of the faeces was significantly lower for the $15 \%$ molasses treatment than for the other two treatments, this was probably not caused by a laxative effect of the molasses. Blaxter et al. (1956) observed differences in faecal DM concentration when the rate of passage of diets through the digestive tract differed. They concluded that a high rate of passage of digesta through the colon limits the time available for water absorption from the digesta. This results in a higher water concentration in the faeces, compared to faeces from digesta moving slowly through the colon. In a previous study (Mavimbela et al., 1997), lambs gained more weight when broiler litter plus 15\% molasses was fed than at lower inclusion levels of molasses. This was suggested to be due mainly to the higher DM intake of the molasses supplemented group. Molasses inclusion at $15 \%$ was thus beneficial to the animals.

The addition of molasses to the litter resulted in a shift in the site of disappearance of OM away from the rumen towards the small intestine. The disappearance of a higher proportion of dietary OM in the small intestine than in the rumen seems abnormal and biologically unlikely. The AFRC (1998) states that 0.550.70 of the digestible energy in a roughage diet typically disappears from the rumen and 0.20-0.35 from the small intestine. To what extent a change in site of digestion would be beneficial or undesirable for animals consuming broiler litter is unclear.

For optimal utilization of dietary $\mathrm{N}$, all $\mathrm{N}$ should be absorbed as amino acids from the small intestine. Oltjen et al. (1968) reported that the rate of ruminal degradation of uric acid was slower than that of urea, and Zinn et al. (1996) estimated that $96 \%$ of uric acid is degraded in the rumen. Previously, Jacobs \& Leibholz (1977) could not detect uric acid in the digesta entering the abomasum of calves, but speculated that undetected uric acid or allantoin might escape rumen degradation. In the present study rumen degradability of $\mathrm{N}$ in broiler litter was estimated to be between 71 and $87 \%$. These values corresponded well with estimates of $85-93 \%$ obtained, using the in situ polyester bag technique (Erasmus, 1990). The smaller loss of dietary $\mathrm{N}(0.26)$ in the rumen with the $15 \%$ molasses treatment compared to the other two treatments ( 0.55 and 0.62 ) may be indicative of improved conversion of dietary $\mathrm{N}$ to microbial $\mathrm{N}$. The microbial- $\mathrm{N}$ yield per g NAN in the abomasum and per unit $\mathrm{N}$ intake increased with the addition of $15 \%$ molasses to litter. However, this was probably not only due to the effect of molasses on microbial growth, but also because of the higher rate of passage of feed through the rumen. It is well documented that a higher rate of passage of feed through the rumen increases the efficiency of microbial protein synthesis in the rumen (AFRC, 1992). It should, however, be stated that the microbial $\mathrm{N}$ yield value of $75.3 \mathrm{~g}$ per $\mathrm{kg}$ of OM digested in the rumen for the $15 \%$ molasses diet seems exceptionally high. Titgemeyer (1997) pointed out that the error factors in partial digestibility studies can be very high.

The $\mathrm{NH}_{3}-\mathrm{N}$ concentrations in ruminal fluid recorded in this study (above $50 \mathrm{mg} / 100 \mathrm{ml}$ ) correspond with the results of Silanikove \& Tiomkin (1992) in which study beef cows consumed $6 \mathrm{~kg}$ of poultry litter and a small quantity of wheat straw per day. These concentrations are well above the range of $2-20 \mathrm{mg}$ $\mathrm{NH}_{3} / 100 \mathrm{ml}$, considered as the optimal for efficient utilization of $\mathrm{NH}_{3}$ by rumen microorganism (Ørskov \& Miller, 1988). A large proportion of dietary N (0.55 and 0.62 respectively) from the $100 \%$ and $92.5 \%$ litter diets must have been absorbed as ammonia through the rumen wall. This is in agreement with the results of Mavimbela et al. (1997) who reported high concentrations of urea in the blood of sheep fed diets containing $85-100 \%$ broiler litter. In a drought feeding situation, where a shortage of energy is the primary problem, the detoxification of excess $\mathrm{NH}_{3}$ in the liver could put an additional strain on the energy and $\mathrm{N}$ metabolism of the body (Lobley et al., 1995). The concentration of $\mathrm{NH}_{3}$ in the rumen did not decrease when $15 \%$ molasses was added, despite the proportional change in site of $\mathrm{N}$ disappearance towards the small intestines. This was probably because of the higher litter intake, and implies that the strain on the body to detoxify $\mathrm{NH}_{3}$ absorbed from the rumen would not have been alleviated by the addition of molasses.

\section{Conclusion}

Considering the apparent improved efficiency of rumen microbial synthesis and a better growth performance of lambs, as observed in a previous trial (Mavimbela et al., 1997), the inclusion of molasses was beneficial to the sheep. However, during a period of drought, the feeding of high levels of litter to sheep might be extravagant and the addition of molasses may be unnecessary except if litter intake can be restricted, or if the voluntary intake of litter is unacceptably low. 


\section{Acknowledgements}

The senior author of this paper passed away before its publication; may he rest in peace. The assistance of R.J. Coertze with statistical analyses is gratefully acknowledged.

\section{References}

AFRC, 1992. AFRC Technical Committee on Response to Nutrients. Report No 9. Nutritive requirements of ruminant animals: Protein. Nutr. Abstr. Rev. (Series B) 62, 787-833.

AFRC, 1998. AFRC Technical Committee on Response to Nutrients. Report No 11. Response in the yield of milk constituents to the intake of nutrients by dairy cow. Nutr. Abstr. Rev. (Series B) 68, 937-989.

AOAC, 1990. Official methods of analysis (15th ed.). Association of Official Analytical Chemists, Inc., Arlington, Virginia, USA.

Bhattacharya, A.N. \& Fontenot, J.P., 1966. Protein and energy value of peanut hull and wood shaving poultry litters. J. Anim. Sci. 25, 367-371.

Blaxter, K.L., Graham, N. Mc C. \& Wainman, F.W., 1956. Some observations on the digestibility of food by sheep, and on related problems. Br. J. Nutr. 10, 69-91.

Chaudry, S.M., Fontenot, J.P., Naseer, Z. \& Ali, C.S., 1996. Nutritive value of deep stacked and ensiled broiler litter for sheep. Anim. Feed Sci. Technol. 57, 165-173.

Downes, A.M. \& McDonald, I.W., 1964. The chromium ${ }^{51}$ complex of ethylene diaminetetraacetac acid as a soluble rumen marker. Br. J. Nutr. 18, 153-162.

Erasmus, L.J., 1990. Die huidige stand van proteïenevaluasie. S. Afr. J. Anim. Sci. 20, 43-51.

Faichney, G.J., 1975. The use of markers to partition digestion within the gastro-intestinal tract of ruminants. In: Digestion and metabolism in the ruminant. Eds. McDonald, I.W. \& Warner, A.C.I., Univ. New England Press, Armidale, NSW, Australia. pp. 277-291.

Fontenot, J.P., 1991. Recycling animal waste by feeding to enhance environmental quality. Prof. Anim. Scientist. 7, 1-8.

Fontenot, J. P. \& Jurubescu, V., 1980. Processing animal waste by feeding to ruminants. In: Digestive physiology and metabolism in ruminants. Eds. Ruckebusch, Y. \& Thivend, P., Avi Publishing Co., Westport, Connecticut.

Jacobs, G.J.L. \& Leibholz, J., 1977. The digestion of dry matter, organic matter and nitrogen in calves fed diets containing broiler litter. J. Agric. Sci., Camb. 90, 367-372.

Lobley, G.E., Connell, A., Lomax, M.A., Brown, D.S., Milne, E., Calder, A.G. \& Farningham, D.A.H., 1995. Hepatic detoxification of ammonia in the ovine liver: possible consequences for amino acid catabolism. Br. J. Nutr. 73, 667-685.

Mavimbela, D.T., Van Ryssen, J.B.J. \& Last, R., 1997. The effect of high broiler litter diets as survival ration on the health of sheep. J. S. Afr. Vet. Assoc. 68, 121-124.

Morgan, P.J.K., Pienaar, J.P. \& Clark, R.A., 1976. Animal based methods of determining herbage intake and quality under grazing conditions. Proc. $5^{\text {th }}$ Congr. Grassl. Soc. 11, 73-78.

Oltjen, R.R., Slyter, L.L., Kozak, A.S. \& Williams, E.E., 1968. Evaluation of urea, biuret, urea phosphate and uric acid as NPN sources for cattle. J. Nutr. 94, 193-202.

Ørskov, E.R. \& Miller, E.L., 1988. Protein evaluation in ruminants. In: Feed Science. World Science Series, B4. Ed. Ørskov, E.R., Elsevier Science, Amsterdam. pp. 103-127.

Patil, A.R., Goetsch, A.L., Kouakou, B., Galloway, D.L., Forester, L.A. \& Park, K.K. 1995. Effects of corn $v s$. corn plus wheat in forage-based diets containing broiler litter on feed intake, ruminal digesta characteristics and digestion in cattle. Anim. Feed Sci. Technol. 55, 87-103.

Park, K.K., Goetsch, A.L., Patil, A.R., Kouakou, B. \& Johnson, Z.B., 1995. Composition and in vitro digestibility of fibrous substrates placed in deep-stacked broiler litter. Anim. Feed Sci. Technol. 54, 159-174.

Rankins, D.L., Eason, J. T., McCaskey, T.A., Stephenson, A.H. \& Floyd, J.G., 1993. Nutritional and toxicological evaluation of three deep-stacking methods for the processing of broiler litter as a foodstuff for beef cattle. Anim. Prod. 56, 321-326.

Robertson, J.B. \& Van Soest, P.J., 1981. The detergent system of analysis and its application to human foods. In: The analysis of dietary fibre in food. Eds. James W.P.T. \& Theader, O., Marcel Dekker, New York. pp. 123-158. 
Rossi, J.E., Goetsch, A.L., Patil, A.R., Kouakou, B., Park, K.K., Wang, Z.S., Galloway, D.L. \& Johnson, Z.B., 1996. Effects of forage level in broiler litter-based diets on feed intake, digestibility and particulate passage rate in Holstein steers at different live weights. Anim. Feed Sci. Technol. 62, 163-177.

Rude, B.J. \& Rankins, D.L., 1997. Mineral status in beef cows fed broiler litter diets with cation-anion differences or supplemented with hay. J. Anim. Sci. 75, 727-735.

Ruffin, G. \& McCaskey, T.A., 1998. Feeding broiler litter to beef cattle. Circular ANR-557, http://gallus.tuma.edu/waste.bfcattle.html.

SAS, 1994. Statistical Analysis Systems User's Guide (6th ed.). SAS Institute Inc., Raleigh, North Carolina.

Siddons, R.C., Nolan, J.V., Beever, D.E. \& MacRae, J.C., 1985. Nitrogen digestion and metabolism in sheep consuming diets containing contrasting forms and levels of nitrogen. Br. J. Nutr. 54, 175-187.

Silanikove, N., Holzer, Z., Cohen, D., Benjamin, R., Gutman, M. \& Meltzer, A., 1987. Interrelationship between metabolism of tritiated water, ${ }^{22}$ sodium and dry matter intake by beef cows fed poultry litter and wheat straw in free choice. Comp. Biochem. Physiol. 88A, 113-118.

Silanikove, N. \& Tiomkin, D., 1992. Toxicity induced by poultry litter consumption: Effect on measurements reflecting liver function in beef cows. Anim. Prod. 54, 203-209.

Titgemeyer, E.C., 1997. Design and interpretation of nutrient digestion studies. J. Anim. Sci. 75, 2235-2247.

Zinn, R.A. \& Owens, F.N., 1986. A rapid procedure for purine measurement and its use for estimating net ruminal protein synthesis. Can. J. Anim. Sci. 66, 157-166.

Zinn, R.A., Barajas, R., Montano, M. \& Shen, Y., 1996. Protein and energy values of dehydrated poultry excreta for feedlot cattle. J. Anim. Sci. 74, 2331-2335. 